April 2013

\title{
In the Interests of Justice: Human Rights and the Right to Counsel in Civil Cases
}

Martha F. Davis

Follow this and additional works at: https://digitalcommons.tourolaw.edu/lawreview

Part of the Civil Rights and Discrimination Commons, Comparative and Foreign Law Commons, Constitutional Law Commons, Human Rights Law Commons, and the International Law Commons

\section{Recommended Citation}

Davis, Martha F. (2013) "In the Interests of Justice: Human Rights and the Right to Counsel in Civil Cases," Touro Law Review. Vol. 25: No. 1, Article 15.

Available at: https://digitalcommons.tourolaw.edu/lawreview/vol25/iss1/15

This Article is brought to you for free and open access by Digital Commons @ Touro Law Center. It has been accepted for inclusion in Touro Law Review by an authorized editor of Digital Commons @ Touro Law Center. For more information, please contact Iross@tourolaw.edu. 


\title{
IN THE INTERESTS OF JUSTICE: Human Rights AND THE Right TO COUNSEl IN CiviL CASES
}

\author{
Martha F. Davis*
}

The Civil Gideon right is an emerging international human right that is receiving increasing recognition on the international stage. As early as the 1940s, the human right to civil counsel was proposed by the United States during the drafting of the Universal Declaration of Human Rights. Though it was not explicitly included in that foundational document, the Civil Gideon right has continued to develop as part of the law of nations. Many individual countries have adopted Civil Gideon rights in particular areas, while the European Court of Human Rights has recognized the importance of the right to civil counsel more broadly as part of a due process right. Most pertinent to the United States, two of the human rights treaties to which the U.S. is a party-the International Covenant on Civil and Political Rights ("ICCPR") and the Convention on the Elimination of All Forms of Racial Discrimination ("CERD")-have been construed by United Nations monitoring bodies to encompass rights to civil counsel. Indeed, the CERD Committee recently urged the United States to address the racially discriminatory impact of its ad hoc approach to Civil Gideon, particularly noting the impact of the lack of counsel on fundamental needs such as housing, safety, sustenance, and familial relationships. In addition to these international guidelines, regional human rights bodies have also addressed the issue.

\footnotetext{
* Professor of Law, Co-Director, Program on Human Rights and the Global Economy ("PHRGE"), Northeastern University School of Law. This Article is based on a 2006 Report issued by PHRGE. This work would not have been possible without the support of Northeastern University School of Law, Dean Emily Spieler, whose insights inspired the initial research, and the Human Rights Program of Harvard Law School. Thanks are also due to the many researchers who contributed to this Article, including Patricia Anders, Kerry Haberlin, Carol Jun, Ambika Panday, Elizabeth Persinger, Jessica Stern, and Jessica White. Raven Lidman, Sarah Paoletti, Hope Lewis, James Rowan, Kyle Courtney, Cathy Albisa, Laura Abel, Andrew Scherer, and Risa Kaufman provided helpful guidance and research suggestions. Patricia Voorhies and Rick Doyon provided terrific technical support.
} 
The Inter-American human rights system, in which the U.S. participates, has issued several strong statements recognizing the importance of a right to counsel to ensure both procedural and substantive fairness in adjudication. These developments point to a growing international consensus that human rights must encompass a right to counsel in cases involving important human needs.

\section{TABLE OF CONTENTS}

INTRODUCTION

I. A BRIEF History OF CIVIL GIDEON

II. Right TO COUNSEL IN CIVIL MATters UNDER

INTERNATIONAL HUMAN RIGHTS LAW ......................................156

A. International Covenant on Civil and Political Rights......157

B. Convention on the Elimination of All Forms of Racial Discrimination 168

C. Other United Nations Documents ..................................174

III. THE INTER-AMERICAN SYSTEM .........................................176

A. The OAS and the American Declaration of the Rights and Duties of Man ....................................................176

B. Components of the Inter-American System ..................179

1. The Inter-American Commission on Human Rights 179

2. The American Convention on Human Rights............ 179

3. Inter-American Court of Human Rights .................. 180

C. Jurisprudence of the Inter-American System ..................180

D. Other OAS Documents.............................................184

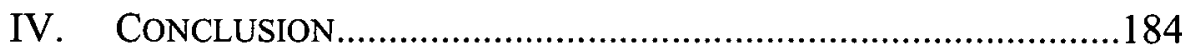




\section{IN THE INTERESTS OF JUSTICE: \\ Human Rights and the Right to Counsel in Civil CASES}

\section{INTRODUCTION}

Article 10 of the Universal Declaration of Human Rights provides that "[e]veryone is entitled in full equality to a fair and public hearing by an independent and impartial tribunal, in the determination of his rights and obligations and of any criminal charge against him." Completed in 1948, the Universal Declaration was intended to give "substance to the term 'human rights' used in the United Nations Charter." While it is simply a declaration, without the legal force of a treaty, the Universal Declaration is widely acknowledged as a fundamental statement of human rights principles, setting out a "universally recognized minimum standard."

The rights articulated in the Universal Declaration span procedural and substantive rights, including a basic right to a fair trial. ${ }^{4}$ Importantly, without dictating specific requirements beyond equality of treatment and an impartial tribunal, Article 10 of the Universal Declaration extends its statement of procedural fairness to civil as

1 Universal Declaration of Human Rights, G.A. Res. 217A (III), art. 10, U.N. GAOR, 3d Sess., 1st plen. mtg., U.N. Doc. A/810 (Dec. 10, 1948), available at http://www.un.org/Overview/rights.html (emphasis added).

2 Manfred Nowak, U.N. Covenant on Civil and Political Rights: CCPR COMMENTARY Xvii (1993).

${ }^{3}$ Id.

${ }^{4}$ See Universal Declaration of Human Rights art. 10, supra note 1 (stating that all people are entitled to a "fair and public hearing"). 
well as criminal matters. ${ }^{5}$ Earlier drafts of the Universal Declaration went further and explicitly stated that everyone in both civil and criminal matters "shall have the right to consult with and to be represented by counsel." However, because the national delegations on the drafting committee agreed that such detailed language belonged in a treaty rather than in the Universal Declaration, the General Assembly of the United Nations ultimately adopted the more general, final version of Article $10 .^{7}$

Nevertheless, the issue of a right to counsel in civil cases has remained a matter of significant concern under international human rights law. Indeed, the right to counsel in civil matters is well established as a general principle of law in the international community. The European Court of Human Rights has construed the European Convention for the Protection of Human Rights and Fundamental Freedoms to require a right to civil counsel. ${ }^{8}$ The Inter-American

${ }^{5}$ Id. ("Everyone is entitled in full equality to a fair and public hearing by an independent and impartial tribunal, in the determination of his rights and obligations and of any criminal charge against him.").

6 David Weissbrodt, Articles 8, 10, and 11 OF The Universal Declaration of HUMAN RIgHTS: THE RIGHT TO A FAIR TRIAL 13 (2001) (describing early drafts of the Universal Declaration).

7 Id. at 14 (noting that India and the United Kingdom initially proposed the right to counsel language be omitted); see David Weissbrodt \& Mattias Hallendorff, Travaux Préparatoires of the Fair Trial Provisions-Articles 8 to 11 -of the Universal Declaration of Human Rights, 21 HUM. RTS. Q. 1061, 1071 (1999).

8 See Convention for the Protection of Human Rights and Fundamental Freedoms, art. 6, Nov, 4, 1950, 213 U.N.T.S. 221 [hereinafter European Convention] (providing that "[i]n the determination of his civil rights and obligations ... . everyone is entitled to a fair and public hearing. . .."). This provision was construed in Airey v. Ireland, to require appointment of civil counsel. Airey v. Ireland, 32 Eur. Ct. H.R. (ser. A) at para. 21 (1979). More recently, the European Court ruled in Steel \& Morris v. United Kingdom, (2005) 41 E.H.R.R. 22, available at http://www.echr.coe.int, that England's legal aid statute denying counsel to indigent defendants in defamation cases violated the right to counsel, and therefore failed to satisfy the European Convention's guarantee of a "fair hearing." 
Court of Human Rights has also recognized the right. ${ }^{9}$ Nations from Ireland to Madagascar provide broad rights to counsel in civil matters, while others, such as South Africa, provide a right to counsel in certain matters involving fundamental rights, such as housing. ${ }^{10}$ Finally, the Human Rights Committee of the United Nations has addressed the right to counsel in civil matters, as have the Committee on the Elimination of All Forms of Racial Discrimination and other United Nations bodies. ${ }^{11}$

The United States, however, lags behind much of the international community in implementing this right. Despite the nation's reputation for setting high standards of procedural fairness, its record of providing counsel in civil matters is poor. ${ }^{12}$ As described below, and in other essays in this Symposium, the federal government has generally left the issue to the states or individual judges, with a resulting patchwork of approaches. ${ }^{13}$ Few would argue that the United States is providing leadership internationally in dealing with this is-

\footnotetext{
9 See Inter-Am. Comm'n on Human Rights, Am. Convention on Human Rights, art. 3, (Jan. 31, 2007), available at http://www.cidh.org/basicos/english/basic3.american\%20convention.htm ("Every person has the right to recognition as a person before the law.").

10 See OPEn SOC'y INST., JuSTICE INITIATIVES 8-21 (Feb. 2004), available at http://www.soros.org/initiatives/osji/articles_publications/publications/justice_20040225 (describing new civil legal aid initiatives of Lithuania and Bulgaria).

11 Compare International Covenant on Civil and Political Rights, G.A. Res. 2200A (XXI), art. 14, §3(d), U.N. GAOR, 21 st Sess., 1495th plen, mtg., U.N. Doc (Dec. 16, 1966) [hereinafter ICCPR] (recognizing only a general right to counsel in criminal matters), with U.N. Comm. on the Elimination of Racial Discrimination [CERD], International Convention on the Elimination of All Forms of Racial Discrimination: Consideration of Reports Submitted by States Parties Under Article 9 of the Convention, CERD/C/USA/CO/6 ๆ 22 (Feb. 18, 2008) ("The Committee further recommends that the State part[ies] allocate sufficient resources to ensure legal representation . . . in civil proceedings. ...").

12 See NowAK, supra note 2, at 236 (noting that the United States Constitution reflects the importance of substantive and procedural due process of law).

${ }^{13}$ See Lassiter v. Dep't of Soc. Servs., 452 U.S. 18, 25 (1981) (holding that only in narrow circumstances may the right to counsel be required in civil proceedings).
} 
sue.

This Article sets out the international law relevant to the right to counsel in civil cases, leaving it to others to use the international framework to illuminate and critique United States' practices. Because of this purpose, this Article examines primarily "universal" standards set by the United Nations or through U.N.-sponsored conferences, and regional human rights law directly relevant to the Americas. In addition to the material covered here, the European Convention on Human Rights also provides an instructive comparative example to the United States, ${ }^{14}$ as do individual nations' approaches to the right to counsel in civil cases. ${ }^{15}$ But this Article's goal is to fill a gap in the existing knowledge by examining the international human rights law most directly relevant to the United States. ${ }^{16}$ As detailed below, these materials lend additional weight to the proposition that a right to counsel in civil cases is an emerging human right necessary to the "interests of justice," and is gaining increasing acceptance in the international community.

14 See, e.g., Justice Earl Johnson, Jr., Equal Access To Justice: Comparing Access to Justice in The United States and Other Industrial Democracies, 24 FORDHAM INT'L L.J. 83, 89 (2000); Raven Lidman, Civil Gideon: A Human Right Elsewhere in the World, 40 CleARINGHOUSE REv. 288, 290-93 (2006) (noting the European system's approach to the right of counsel in civil cases).

15 See Lidman, supra note 14, at 291 n.29; see also Raven Lidman, Civil Gideon as a Human Right: Is the U.S. Going to Join Step With the Rest of the Developed World, 15 TEMP. POL. \& CIV. RTS. L. REV. 769, 774-78 (2006) (describing the right to counsel in civil proceedings in foreign jurisdictions).

16 See Sarah Paoletti, Deriving Support From International Law for the Right to Counsel in Civil Cases, 15 TEMP. POL. \& CIV. RTS. L. REV. 651 passim (2006) (comparing the United States to its foreign counter-part, the European Union, which recognizes a right to counsel in civil proceedings). 


\section{A BRIEF History OF CiviL Gideon}

For more than forty years, legal counsel has been constitutionally guaranteed to individuals in the United States facing criminal charges that may result in their loss of liberty. The United States Supreme Court in Gideon v. Wainwright, ${ }^{17}$ held that the Sixth Amendment to the United States Constitution required counsel to be appointed to those who were too poor to afford it based on the unfair reality that "in our adversary system of criminal justice, any person haled into court, who is too poor to hire a lawyer, cannot be assured a fair trial unless counsel is provided for him." 18 In contrast, the United States Supreme Court in Lassiter v. Department of Social Services held that there is no absolute right to counsel in civil proceedings, with the Court specifically addressing the parental rights of an indigent litigant. ${ }^{19}$ Rather than recognize such a right, the Court instructed lower courts to apply a balancing test to determine whether counsel should be appointed in any given case, combining the test with an overlying presumption against appointed counsel except when there is a risk of loss of physical liberty. ${ }^{20}$ Until recently, the Lassiter decision had a chilling effect on domestic litigation and ad-

17372 U.S. 335 (1963).

18 Id. at 344.

19 Lassiter, 452 U.S. at 31 ("[T]here is no right to appointed counsel in the absence of at least a potential deprivation of physical liberty....").

20 Id. at 26-27.

[T]he Court's precedents speak with one voice about what "fundamental fairness" has meant when the Court has considered the right to appointed counsel, and we thus draw from them the presumption that an indigent litigant has a right to appointed counsel only when, if he loses, he may be deprived of his physical liberty. It is against this presumption that all the other elements in the due process decision must be measured.

Id. 
vocacy supporting a right to counsel in civil cases, a so-called "Civil Gideon" right. But, as the American Bar Association recently observed, "in the last few years advocates around the country have taken up the challenge with renewed vigor and strategic thinking.",21 Cases seeking to establish a right to counsel in civil matters have been brought in Maryland, Washington, and Ohio, among others. ${ }^{22}$ Additional legislative campaigns are underway in California and New York. $^{23}$

The current law remains a patchwork, however. Roth before and after Lassiter, some state courts and state legislatures have expanded the right to counsel in some civil cases. For example, in 1973 the Maine Supreme Court ruled that counsel must be provided by the state to parents in dependency and neglect cases. ${ }^{24}$ Oregon and Alaska courts have reached similar conclusions. ${ }^{25}$ More recently, a federal district court in Georgia, construing the state constitution, held that foster care children have a right to counsel in abuse and neglect proceedings and other so-called "deprivation cases." 26 Simi-

21 See AM. BAR Ass'N TASK FORCE ON ACCESS to Civil JustiCE, REPORT to THE House of DELEGATES $10 \quad$ (2006), available at http://www.abanet.org/legalservices/sclaid/downloads/06A112A.pdf [hereinafter ABA, REPORT TO THE HOUSE OF DELEGATES].

22 See, e.g., id. at 11. See Nat'l Coalition for Civil Right to Counsel, Homeowners Facing Foreclosure Ask Ohio Supreme Court to Order Appointment of Counsel, http:// www.civilrighttocounsel.org/advocacy/litigation/ (last visited Sept. 17, 2008). The webpage also provides a link to other state court decisions where courts have ruled on a civil right to counsel.

${ }^{23}$ See, e.g., Nat'l Coalition for Civil Right to Counsel, New York City Bill Would Provide Counsel for Seniors Facing Eviction, http://www.civilrighttocounsel.org/advocacy/legislation/ (last visited Sept. 17, 2008).

24 Danforth v. State Dep't of Health and Welfare, 303 A.2d 794, 800 (Me. 1973).

25 See Flores v. Flores, 598 P.2d 893, 896 (Alaska 1979); State v. Jamison, 444 P.2d 15, 17 (Or. 1968).

${ }^{26}$ Kenny A. ex rel. Winn v. Perdue, 356 F. Supp. 2d 1353, 1359 (N.D. Ga. 2005) ("[T]he Court concludes that such a right is guaranteed under the Due Process Clause ... of both the 
larly, some state and municipal legislatures have begun to address Civil Gideon issues, considering whether to extend procedural protections such as the right to counsel in some civil matters such as housing or parental termination cases. ${ }^{27}$ Despite these developments, however, nowhere in the United States is the right comprehensive.

The Civil Gideon movement took a step forward in August 2006 when the American Bar Association unanimously endorsed a resolution calling on

[F]ederal, state, and territorial governments to provide legal counsel as a matter of right at public expense to low income persons in those categories of adversarial proceedings where basic human needs are at stake, such as those involving shelter, sustenance, safety, health or child custody, as determined by each jurisdiction. $^{28}$

Significantly, the ABA Resolution calls for Civil Gideon rights in cases considered to "involve interests so fundamental and important as to require governments to supply low income persons with effective access to justice as a matter of right." 29 These "fundamental interests" to shelter, sustenance, safety, health, and child custody parallel fundamental economic and social rights found in many of the world's constitutions and in international human rights treaties, but

\footnotetext{
United States and Georgia Constitutions ....").

27 Andrew Scherer, Why People Who Face Losing Their Homes in Legal Proceedings Must Have a Right to Counsel, 3 CARdozo PuB. L. PoL'Y \& ETHICs J. 699, 730 (2006); see Nat'l Coalition for Civil Right to Counsel, Louisiana Statute Provides Appointed Counsel for Parents Facing Termination of Parental Rights in Intra-Family Adoption Proceedings, http://www.civilrighttocounsel.org/advocacy/legislation/ (last visited Nov. 25, 2008) (describing a new Louisiana law extending appointed counsel in parental termination cases).

28 ABA, REPORT TO THE HOUSE OF DELEGATES, supra note 21 , at 1 .

29 Id. at 13.
} 
are not explicitly protected by the United States Constitution.

The ABA's focus on fundamental economic and social rights as a basis for triggering the right to counsel provides an appropriate starting place for implementation, because it prioritizes needs that are widely recognized as compelling. In addition, the confluence highlighted by the ABA between important procedural rights and substantive economic and social rights provides a compelling reason to examine international human rights law relevant to Civil Gideon claims.

\section{Right TO COUNSEl In Civil MATters UNDER INTERNATIONAL HUMAN RightS LAW}

The right to counsel in civil matters is explicitly referenced in the text of only one of the international human rights treaties in which the United States is a participant: the Charter of the Organization of American States ("OAS"). ${ }^{30}$ However, as described below, the wealth of relevant interpretive material combined with the weight of considerable international practice make clear that provision of counsel in civil matters is an emerging human right increasingly recognized by the law of nations, especially when the civil matter at issue involves fundamental rights. Set out below are the relevant text and interpretations of the International Covenant on Civil and Political Rights ("ICCPR"), the Convention on the Elimination of All Forms of Race Discrimination (“CERD”), other relevant United Nations

30 Charter of the Organization of American States art. 45, opened for signature Apr. 30, 1948, 2 U.S.T. 2394, 1609 U.N.T.S. 119 (entered into force Dec. 13, 1951) amended by Protocol of Buenos Aires, O.A.S.T.S. No. 1-A (1967), further amended by Protocol of Cartagena, O.A.S.T.S. No. 66 (1985), further amended by Protocol of Washington, OEA/Ser.A/2 Add. 3 (SEPF) (1992), further amended by Protocol of Managua, OEA/Ser.A/2 Add. 4 (SEPF) (1993). 
documents, and the Inter-American Human Rights system. This Article focuses on the ICCPR and CERD because these treaties have been ratified by the United States and, therefore, create binding international obligations on both the national government and the states. ${ }^{31}$

\section{A. International Covenant on Civil and Political Rights}

The United Nations Commission on Human Rights began drafting the "International Bill of Human Rights" (consisting of the ICCPR and the International Covenant on Economic, Social and Cultural Rights ("ICESCR")) in the late 1940s, concurrently with the Universal Declaration. In part because of the intervening Cold War, however, the ICCPR and ICESCR were not completed until 1966, when they were adopted by the United Nations. ${ }^{32}$ The United States formally ratified the ICCPR on September 8, 1992; it has not ratified the ICESCR. ${ }^{33}$ Unlike the nonbinding Universal Declaration, the ICCPR is a formal legal document creating obligations on the part of participating nations. In ratifying the treaty, the United States undertook "to respect and to ensure to all individuals within its territory and subject to its jurisdiction the rights recognized in the . . Cove-

31 Though these treaties are not self-executing and may, therefore, not be "Supreme" domestic law under the United States Constitution's Supremacy Clause, absent congressional implementation, they nevertheless create international obligations that should influence state policies. See Medellin v. Texas, 128 S. Ct. 1346, 1373, 1374 (2008) (Stevens, J., concurring); Martha F. Davis, Upstairs, Downstairs: Subnational Incorporation of Human Rights Norms at the End of an Era, 77 FORDHAM L. REV. 411, 433-35 (2008).

32 John Shattuck, The Legacy of Nuremberg: Confronting Genocide and Terrorism Through the Rule of Law, 10 GONZ. J. INT'L L. 6, 8 (2006-2007).

33 Research and Library SERV. Div., The IMPLEMENTATION OF THE INTERNational COVENANT ON ECONOMIC, SOCIAL AND CULTURAL RighTS IN OVERSEAS JURISDICTIONS AND HONG KONG 4 (Apr. 1995), available at www.legco.gov.hk/yr9798/english/sec/library/9495rp02e.pdf. 
nant, without distinction of any kind." ${ }^{.34}$ The United States also adopted specific reservations, understandings, and declarations intended to modify its general obligations. For example, the United States indicated that the treaty would not be "self-executing," but would require specific implementation by Congress. ${ }^{35}$ This understanding does not affect the nation's obligation to comply with the ICCPR, but limits the ability of litigants to rely directly on the treaty in domestic litigation. ${ }^{36}$

The ICCPR's Article 14 directly addresses fairness before domestic courts and tribunals in both civil and criminal matters, providing that:

All persons shall be equal before the courts and tribunals. In the determination of any criminal charge against him, or of his rights and obligations in a suit at law, everyone shall be entitled to a fair and public hearing by a competent, independent and impartial tribunal established by law. ${ }^{37}$

Similarly, Article 2 of the ICCPR requires that States Parties undertake to "ensure that any person whose rights or freedoms as herein recognized are violated shall have an effective remedy," including

\footnotetext{
34 ICCPR, art. 2, supra note 11 , at 52.

35 See International Covenant on Civil and Political Rights, 138 Cong. Rec. S4781-01, S4783 (1992) (statement of Senator Moynihan).

36 See, e.g., U.S. Initial Report to the Comm. on the Elimination of Racial Discrimination Addendum, $\S$ B5, U.N. Doc. CERD/C/351/Add.1 (Sept. 21, 2000), available at http://wwwl.umn.edu/humanrts/usdocs/cerdinitial.html (noting that "[t]his declaration has no effect on the international obligations of the United States"). See also Medellin, $128 \mathrm{~S}$. Ct. at 1368-69 (holding that the President alone could not require Texas to comply with a non-self-executing treaty absent Congressional implementation).

37 International Covenant on Civil and Political Rights, art. 14(1) (New York, 16 Dec. 1966) 999 U.N.T.S. 171 and 1057 U.N.T.S. 407, entered into force 23 Mar. 1976 [the provisions of article 41 (Human Rights Committee)] entered into force 28 Mar. 1979.
} 
determination of the rights by a "competent authority." 38 The obligations in both Articles 3 and 14 constitute positive duties; States Parties are obligated to take affirmative steps to implement the rights.

While the final text is silent on the right to counsel in civil matters, earlier versions of the ICCPR specifically addressed the issue. For example, the initial proposal offered by the United States urged the following language: "In the determination of his rights and obligations, everyone is entitled to . . . the aid of counsel."39 The Chairman of the Working Group charged with drafting the Covenant, Lord Dukestone of the United Kingdom, suggested substituting the words "qualified representative" for "counsel." 40 With that substitution, the proposed Covenant was forwarded to the United Nations Economic and Social Council in $1947 .^{41}$ Commenting on the proposal in May 1948, however, the United Kingdom suggested limiting the right to assistance to criminal cases or matters involving the vindication of human rights. ${ }^{42}$ In response, a subcommittee consisting of France, the United Kingdom, and the United States convened to revise the proposal. ${ }^{43}$

The revised draft that the subcommittee proposed, adopted by the ICCPR Drafting Committee, eliminated entirely the specific language concerning the right to counsel in civil cases. ${ }^{44}$ While the evidence is ambiguous, some of the discussions surrounding the simul-

38 Id. at art. 2, § 3(a), (b).

39 WEISSBRODT, supra note 6 , at 45.

40 Id. at 46.

41 Id.

42 Id. at 47.

${ }^{43} I d$. at 47-48.

44 WEISSBRODT, supra note 6 , at 48. 
taneous drafting of the Universal Declaration and the ICCPR suggest the language concerning civil counsel might have been deemed less critical than the provision addressing criminal counsel because "there were some countries where counsel was secured in civil but not criminal proceedings." ${ }^{45}$ In any event, this pared-down version of Article 14(1) was ultimately incorporated into the final version of the ICCPR. ${ }^{46}$ And while the ICCPR does not explicitly address a right to civil counsel, Article 14(3)(d) of the ICCPR still provides for a right to counsel in criminal matters. Specifically, the ICCPR provides that everyone facing a criminal charge has the following right:

[T]o defend himself in person or through legal assistance of his own choosing; to be informed, if he does not have legal assistance, of this right; and to have legal assistance assigned to him, in any case where the interests of justice so require, and without payment by him in any such case if he does not have sufficient means to pay for it. ${ }^{47}$

Though no longer explicit in the text, the principle of access to civil counsel articulated by the United States delegation remains relevant to the meaning of Article $14 .^{48}$ Indeed, as the jurisprudence under the ICCPR develops, interpretations of the ICCPR come closer

45 Weissbrodt \& Hallendorff, supra note 7, at 1070. Weisbrodt and Hallendorff discuss the similar provisions in the Universal Declaration and the ICCPR.

46 ICCPR, art. 14(1), supra note 11.

47 ICCPR, art. 14(3)(d), supra note 11.

48 Interestingly, the United States has continued to use access to counsel in civil cases as one indicator of nations' respect for human rights. See, e.g., Press Release, United States Department of State, Maldives - Country Reports on Human Rights Practices, 2003 (Feb. 25,2004 ), available at http://www.state.gov/g/drl/rls/hrrpt/2003/27948.htm (noting that "[c]ourts adjudicating matrimonial and criminal cases generally do not allow legal counsel in court"). 
to the initial approach proposed by the United States and later endorsed by the United Kingdom in its suggestion that counsel be provided in those cases involving fundamental human rights. ${ }^{49}$ The principal interpretive body of the ICCPR is the Human Rights Committee ("HRC"), established by the ICCPR to (1) review States' periodic reports on their compliance with the ICCPR; ${ }^{50}(2)$ respond to individuals who allege that their rights have been violated by one of the States that have ratified the Optional Protocol to the ICCPR; ${ }^{.51}$ and (3) adopt General Comments interpreting the provisions of the Covenant. $^{52}$

In 1984, the HRC issued General Comment No. 13, reminding participating nations that Article 14 applies to civil as well as criminal proceedings. ${ }^{53}$ The Committee noted that "[i]n general, the reports of States Parties fail to recognize that article 14 applies not only to procedures for the determination of criminal charges against individuals but also to procedures to determine their rights and obligations in a suit at law." ${ }^{, 54}$ In light of this, the HRC asked that States Parties provide "all relevant information and . . . explain in greater

49 U.S. Senate Comm. on Foreign Relations, Report on the International Covenant on Civil and Political Rights, S. Exec. Rep. No. 23, 3 (102d Sess. 1992), reprinted in 31 I.L.M. 645 (1992) [hereinafter Senate Comm. Report].

so Id. at 3-4.

51 Optional Protocol to the ICCPR, G.A. res. 2200A (XXI), 21 U.N. GAOR Supp. (No. 16) at 59, U.N. Doc. A/6316 (1966), 999 U.N.T.S. 302, entered into force March 23, 1976.

52 Id. at 57.

53 United Nations, Int'l Human Rights Instruments, Human Rights Comm. General Comment 13, art. 14 (21 st sess., 1984) $\mid 2$, Compilation of General Comments and General Recommendations Adopted by Human Rights Treaty Bodies, UN Doc. HRI IGENIIVRev.1, at 14 (1994). The timing of this General Comment suggests that the U.S. Supreme Court's 1981 decision in Lassiter may have generated some concern that participating nations would begin to back away from extending broad due process protections, including the right to counsel in civil proceedings.

54 Id. $ๆ 2$. 
detail how the concepts of 'criminal charge' and 'rights and obligations in a suit at law' are interpreted in relation to their respective legal systems." $" 55$

In 2007, the HRC issued new General Comment No. 32, which replaced General Comment No. 13. This more recent Comment also construes Article 14, focusing on the rights to equality before courts and tribunals and to a fair trial. In discussing the right to counsel, the Comment specifically notes that "[s]tates are encouraged to provide free legal aid in [noncriminal cases], for individuals who do not have sufficient means to pay for it. In some cases, they may even be obliged to do so."56 Further, the new General Comment includes a discussion of the concept of "equality of arms," clarifying that the procedures for handling criminal and civil matters must be fundamentally fair. ${ }^{57}$

In conformity with both the earlier General Comment No. 13 and new General Comment No. 32, countries often affirmatively address the issue of counsel in civil matters in their compliance reports filed with the HRC. For example, Canada's report of October 2005 specifically noted the 1999 Supreme Court case New Brunswick (Minister of Health and Community Services) v. G.J., which concluded that "the government may be required to provide an indigent party with state-funded counsel" in a child custody case. ${ }^{58}$ Likewise,

\footnotetext{
55 Id.

56 United Nations, Human Rights Committee-General Comment No. 32 (90th sess. 2007) CCPR/C/GC/32, para. 10, available at http://www2.ohchr.org/english/bodies/hrc/docs/gcartl4.doc.

57 Id. at para. 13.

58 United Nations, ICCPR - Consideration of Reports Submitted By States Parties Under Article 40 of the Covenant-Fifth Periodic Report: Canada, I 95 (2004),
} 
Madagascar affirmatively reported that its constitution guarantees legal assistance in civil as well as criminal cases if the plaintiff or defendant cannot afford it. ${ }^{59}$ Germany's 2002 report to the HRC also underscored its commitment to providing universal legal aid. ${ }^{60}$

In addition, the HRC has gone beyond its general commentary to clarify that legal assistance may be required to ensure fairness in certain civil cases in legal systems based on both common law and civil law traditions. The HRC has frequently sought information on civil legal assistance from the countries appearing before it. On some occasions, when the HRC has found a country's initial report wanting, it has specifically inquired regarding the right to counsel in civil matters. ${ }^{61}$ For example, in commenting on Spain's compliance report, the HRC asked "whether legal aid was available in both civil and criminal cases." ${ }^{62}$ Spain's response, noted in the HRC's Conclud-

CCPR/C/CAN/2004/5.

59 United Nations, ICCPR - Consideration of Reports Submitted By States Parties Under Article 40 of the Covenant-Third Periodic Report: Madagascar, If 22-23 (2005), $\mathrm{CCPR} / \mathrm{C} / \mathrm{MDG} / 2005 / 3$.

${ }^{60}$ United Nations, ICCPR - Consideration of Reports Submitted By States Parties Under Article 40 of the Covenant-Fifth Periodic Report: Germany, I 190 (2002), CCPR/C/DEU/2002/5.

${ }^{61}$ See, e.g., Annual Report of the Comm. to the General Assembly: 9th Report, USS, para. 287, U.N. Doc. A/40/40 (1985) (requesting information on the availability of free legal assistance for persons seeking legal advice); Annual Report of the Committee to the General Assembly: 10th Report, Czechoslovakia, I 344, 27th Sess., U.N. Doc. A/4 1/40 (1986) (noting questions relating to legal services); Consideration of Reports Submitted by States Parties under Article 9 of the Convention, Concluding Observations of the Human Rights Comm., Brazil, at 5, I. 17, 88th Sess., U.N. Doc. CCPR/C/BRA/CO/2 (2005) (stating the Committee's "concern[] about a lack of access to counsel and legal aid").

62 Annual Report of the Comm. to the General Assembly: 9th Report, Spain, para. 419, U.N. Doc. A/40/40 (1985). Spain's legal system is based on the civil law tradition. See also List of Issues: Trinidad and Tobago 16/08/2000. CCPR/C/70/TTO, I 12 ("Is legal aid in order to protect Covenant rights available and is it being properly funded?"); Summary Record of the 1870th Meeting: Trinidad and Tobago, 23/10/2000, 70th Sess., U.N. Doc. CCPR/C/SR.1870 (2000). In the live exchange with the HRC, the representative of Trinidad and Tobago testified concerning the number of civil matters funded by legal aid. Id. I 32 . Members of the HRC then probed further concerning the method of paying legal aid attor- 
ing Observations, was that the right to assistance "applied to both criminal and civil cases, subject only to the defendant's need." 63

Similarly, the committee sought clarification from the United Kingdom, a common law nation, regarding whether "legal aid was provided for in both civil and criminal cases." ${ }^{64}$ Again, the country's response-that both civil and criminal legal aid was available provided that the litigant was income-eligible - was noted in the HRC's Concluding Observations. ${ }^{65}$ The HRC has also expressed "satisfaction" concerning Ireland's scheme of providing legal services "to persons of modest means at little or no cost," improvements made by Italy - with a civil law system - in its free legal aid scheme. ${ }^{67}$

Further, the HRC has linked the availability of legal assistance in civil matters directly to its assessment of the country's compliance with the ICCPR. For example, responding to Zimbabwe's report in 1998, the HRC welcomed legislative changes to permit a widow to inherit her deceased husband's estate. However, the Committee specifically sought further information "on the steps taken to ensure that widows are made aware of this right and that legal assis-

neys, id. ๆ 41 (Mr. Scheinin), and whether counsel was available on appeal. Id. If 74 (Ms. Evatt).

${ }^{63}$ U.N. Report of the Human Rights Comm., Concluding Observations-CCPR - Spain, I 494, U.N. Doc. A/34/40 (1979).

${ }^{64}$ Annual Report of the Comm. to the General Assembly: 9th Report, United Kingdom, I 561, U.N. Doc. A/40/40 (1985).

65 Id. ๆ 563.

66 U.N. Report of the Human Rights Comm., Concluding Observations-CCPR-Ireland, ๆ 430, U.N. Doc. A/55/40 (2000).

${ }_{67}$ U.N. Report of the Human Rights Comm., Concluding Observations-Italy, fT 271-90, CCPR/C/79/Add.37; A/49/40 (1994). 
tance be provided for their benefit." 68

The HRC's more recent concluding remarks address the right to counsel in civil matters even more directly. In evaluating United States compliance with the ICCPR in 2006, the HRC commented that "[d]ue process," including "access of detainees to counsel of their choice ... should be guaranteed." ${ }^{\circ 9}$ Of course, the differences between the detention of individuals in Guantanamo and criminal detention are slight at best. However, in other circumstances more distinct from criminal matters, the $\mathrm{HRC}$ has made clear the right to counsel is central to its vision of due process in civil contexts. For example, in examining the Czech Republic's periodic report in 2007 , the HRC expressed concern over the housing situations facing Roma, including forced evictions and substandard quality. The HRC specifically urged the Czech Republic to "[p]rovide legal aid for victims of discrimination" as part of its implementation of the ICCPR. ${ }^{70}$ Similarly, expressing concern about restrictions on trade unions and worker activism in Chile, the HRC concluded that "[ $\mathrm{t}]$ he State party should . . make legal aid available to workers to enable their complaints to be successfully heard."

In addition to reviewing country reports on ICCPR compliance, the HRC also considers matters coming before it under the

68 U.N. Report of the Human Rights Comm., Concluding Observations-Zimbabwe, at ๆ13, CCPR/C/79/Add. 89 (1998). Zimbabwe's legal system combines elements of common law and civil law.

69 U.N. Report of the Human Rights Comm., Concluding Observations-United States of America, \18, CCPR/C/USA/CO/3/Rev. 1 (2006).

${ }^{70}$ U.N. Report of the Human Rights Comm., Concluding Observations--Czech Republic, I 16, CCPR/C/CZE/CO/2 (2007).

71 U.N. Report of the Human Rights Comm., Concluding Observations-Chile, If 14, CCPR/C/CHL/CO/5 (2007). 
ICCPR's Optional Protocol that permits consideration of individual grievances against States Parties. ${ }^{72}$ After extensive research, I have identified no cases in which the HRC found that the issue of the right to counsel in a civil context was properly raised by the complainant. ${ }^{73}$ However, the HRC has considered many cases concerning the right to counsel in criminal matters. Interestingly, as echoed in General Comment No. 32, these cases often raise the general principle of "equality of arms" between the plaintiff and respondent, noting that it is an important component of a fair trial. ${ }^{74}$ This principle is violated when the imbalance of access and power is so great that it threatens the fairness of the proceeding.

Two cases raising the "equality of arms" issue illuminate the HRC's view of the scope of Article 14: Oló Bahamonde v. Equatorial Guinea $^{75}$ and Currie v. Jamaica. ${ }^{76}$ Both cases concerned the availability of legal aid in a criminal proceeding.

Oló Bahamonde claimed that he experienced discrimination by the government of Equatorial New Guinea based on his clan membership. He alleged that as part of this discriminatory treatment, he was arbitrarily arrested and detained, and was prevented from pursuing domestic remedies. ${ }^{77}$ In reviewing Bahamonde's complaint,

\footnotetext{
72 Office of the United Nations High Comm'r for Human Rights, Human Rights Comm: Monitoring Civil and Political Rights, http://www2.ohchr.org/english/bodies/hrc/index.htm (last visited Aug. 27, 2008).

73 WEISSBRODT, supra note 6, at 130.

74 NowAK, supra note 2, at 246-47.

75 Oló Bahamonde v. Equatorial Guinea, Communication No. 468/1991, U.N. Doc. CCPR/C/49/D/468/1991 (1993).

76 Currie v. Jamaica, Communication No. 377/1989, U.N. Doc. CCPR/C/50/D/377/1989 (1994).

77 Bahamonde, 13.2.
} 
the HRC noted generally "that the notion of equality before the courts and tribunals encompasses . . . access to the courts and that a situation in which an individual's attempts to seize the competent jurisdictions of his/her grievances are systematically frustrated runs counter to the guarantees of article 14, paragraph 1."78 Consistent with the HRC's statements in its Concluding Observations, this expansive language suggests that the equality of arms principle may build on the general language of Article 14(1) to require that in certain circumstances, litigants have equal access to counsel in civil as well as criminal matters.

In Currie, in contrast, the HRC initially leveled its gaze on the meaning of ICCPR Article 2. Anthony Currie, a Jamaican citizen, was charged with murder and sentenced to death. In the absence of legal assistance and without a written judgment issued by the court of appeals reviewing his case, he was unable to obtain any higher court review under domestic law and he appealed to the HRC. In sweeping terms, the HRC observed that " $[\mathrm{t}]$ he State party has an obligation, under article 2, paragraph 3 , of the Covenant, to make the remedies in the Constitutional Court addressing violations of fundamental rights available and effective."79 The HRC then noted that "the Covenant does not contain an express obligation as such for a State to provide legal aid for individuals in all cases," but only in those criminal cases where the "interests of justice so require."

Though it restates the obvious absence of specific language

78 Id. ๆ 9.4.

79 Currie, 113.3.

$80 \quad$ Id. ๆ 13.2. 
concerning civil counsel, this statement seems principally intended to emphasize the limiting principle represented by the "interests of justice" standard. Applying that standard in Currie, the HRC concluded that the interests of justice were implicated, and that the absence of legal aid denied the complainant the opportunity to test the propriety of his criminal trial. ${ }^{81}$ Again, while more attentive to the ICCPR's text than the HRC's opinion in Bahamonde, the approach adopted in Currie suggests that twin considerations of the "interests of justice" and "equality of arms" may be the principle vehicles for construing and applying Article 14(1). Further, the HRC's conclusions indicate that the "interests of justice" may be most weighty when fundamental rights are at stake.

In sum, the ICCPR's drafting history and its subsequent construction and enforcement by the ICCPR, as well as participating nations provides considerable confirmation that the right to counsel in civil cases is an emerging human right in the international community.

\section{B. Convention on the Elimination of All Forms of Racial Discrimination}

The principle of equality addressed in the ICCPR is the central focus of the International Convention on the Elimination of All Forms of Racial Discrimination ("CERD"). CERD was adopted and opened for signature and ratification on December 21, 1965, and entered into force on January $4,1969 .^{82}$ The United States joined in

81 Id. |ा 13.4.

82 International Convention on the Elimination of All Forms of Racial Discrimination, 
ratifying CERD in $1994 .^{83}$ The United Nations created the Committee on the Elimination of Racial Discrimination ("CERD Committee") to monitor and review actions by CERD's participating states. Under CERD, like the ICCPR, each States Parties must submit regular reports to the CERD Committee detailing the implementation of their obligations under the Covenant. ${ }^{84}$

Several provisions of CERD address fair procedure and adjudication through the lens of equality and nondiscrimination. For example, Article 5 requires that States Parties undertake "to guarantee . . . $[t]$ he right to equal treatment before the tribunals and all other organs administering justice." 85 Addressing the remedies available to victims of discrimination, Article 6 provides that

States Parties shall assure to everyone within their jurisdiction effective protection and remedies, through the competent national tribunals and other State institutions, against any acts of racial discrimination which violate his human rights and fundamental freedoms contrary to this Convention, as well as the right to seek from such tribunals just and adequate reparation or satisfaction for any damage suffered as a result of such discrimination. ${ }^{86}$

Both of these formulations encompass civil matters, and explicitly

G.A. Res. 2106 (XX), Annex, 20 U.N. GAOR Supp. (No. 14) at 47, U.N. Doc. A/6014 (1966), 660 U.N.T.S. 195 (entered into force Jan. 4, 1969).

${ }^{83}$ See 140 Cong. Rec. S7634-02 (daily ed. June 24, 1994).

84 JusticeInitiative.org, The CERD: Provisions, Reporting Mechanisms and Individual Complaints, http://www.justiceinitiative.org/activities/ec/ec_russia/moscow_workshop/plese (last visited Aug. 27, 2008).

85 International Convention on the Elimination of All Forms of Racial Discrimination, art. 5(a), opened for signature Dec. 21, 1965, S. Exec. Doc. C, 95-2, at 3 (1978), 660 U.N.T.S. 195 (entered into force Jan. 4, 1969; for United States Nov. 20, 1994).

${ }^{86} \mathrm{Id}$. at art. 6. 
require that States take positive steps to ensure effective access to the apparatus of the State's justice system.

As the principal body with responsibility for interpreting and implementing CERD, the CERD Committee issues General Recommendations to assist nations with the task of implementing CERD's provisions. In its recently-issued General Recommendation 31 "on the prevention of racial discrimination in the administration and function of the criminal justice system," the CERD Committee highlighted the importance of making it easier for victims of acts of racism to seek civil redress in the courts by, inter alia, providing free assistance of counsel. Specifically, in Section C, paragraph (17)(b), the CERD Committee commented,

In order to make it easier for the victims of acts of racism to bring actions in the courts, the steps to be taken should include the following:

Granting victims effective judicial cooperation and legal aid, including the assistance of counsel and an interpreter free of charge. ${ }^{87}$

General Recommendation No. 29 addressing "[d]iscrimination based on [d]escent," similarly recommends that States Parties "[t]ake the necessary steps to secure equal access to the justice system for all members of descent-based communities, including by providing legal aid, facilitating of group claims and encouraging non-governmental

87 U.N. Report of the CERD, General Recommendation No. 31: Prevention of Racial Discrimination in the Administration and Functioning of the Criminal Justice System, U.N. Comm. on the Elimination of Racial Discrimination, 60th Sess., Supp. No. 18, at 103 I C(17)(b), U.N. Doc. A/60/18 (2005). 
organizations to defend community rights." 88 More generally, General Recommendation No. 20 on the guarantee of human rights free from racial discrimination states that " $[\mathrm{m}]$ any of the rights and freedoms mentioned in article 5 , such as the right to equal treatment before tribunals, are to be enjoyed by all persons living in a given State." 89

In monitoring CERD's implementation, the CERD Committee has also been mindful of the importance of legal aid in ensuring equal access to the courts and in enlisting the existing mechanisms of government in combating racial discrimination. Responding to these cues, nations filing reports with the CERD Committee routinely describe their schemes for providing legal aid in civil cases. ${ }^{90}$ The CERD Committee has also commented favorably on participating States' efforts to expand and improve civil legal aid. ${ }^{91}$ When countries have fallen short in implementing CERD's provisions, the CERD Committee has specifically urged that they expand access to civil legal aid as one aspect of increasing their compliance with CERD. ${ }^{92}$

88 U.N. Report of the CERD, General Recommendation No. 29: Discrimination Based on Descent, U.N. Comm. on the Elimination of Racial Discrimination, 61st Sess., at 111 If 5(u), U.N. Doc. A/57/18 (2002).

${ }^{89}$ U.N. Report of the CERD, General Recommendation No. 20: Compilation of General Comments and General Recommendations Adopted by Human Rights Treaty Bodies, 48th Sess., at 209 ๆ 3, U.N. Doc. HRI/GEN/1/Rev.6 (2003).

90 See, e.g., U.N. CERD-Consideration of Reports Submitted By States Parties Under Article 9 of the Convention, Thirteenth Periodic Reports of States Parties Due in 1994Nigeria, II 27, U.N. Doc. CERD/C/263/Add.3 (1994) (State Party Report).

91 U.N. CERD Report, Concluding Observations of the Comm. on the Elimination of Racial Discrimination-Norway, ๆ 3, 18/09/97, U.N. Doc. CERD/C/304/Add.40 (1997) (noting Norway's establishment of a "working group which has a mandate to improve legal aid available to victims of racial discrimination").

92 See, e.g., U.N. CERD Report, Concluding Observations of the Comm. on the Elimination of Racial Discrimination-Republic of Korea, I 19, 07/04/99, U.N. Doc. 
These recommendations have often focused on the inequality that arises when legal aid is not widely available. For example, in commenting on Botswana's report, the CERD Committee expressed concern regarding "the reported difficulties experienced by poor people, many of whom belong to San/Basarwa groups and other nonTswana tribes, in accessing common law courts, due in particular to high fees [and] the absence of legal aid in most cases." mittee recommended that legal aid be provided "especially to persons belonging to the most disadvantaged ethnic groups, to ensure their full access to justice." ${ }^{94}$ Similarly, in reviewing Madagascar's most recent report, CERD noted the limited number of cases brought by victims of racial discrimination and posited this might be "the result of, inter alia, the limited resources available to them." $" 95$ To address this human rights issue, CERD urged Madagascar to "make it easier for victims to gain access to justice, in particular through the effective application of a system of legal aid." "96 CERD's strongest statement to date on the importance of civil counsel was issued in the course of a recent review of the United States' compliance with CERD. The CERD Committee noted "with concern the disproportionate impact that the lack of a generally recognised right to counsel in civil pro-

CERD/C/304/Add.65 (1999) (recommending that "the State party provide legal aid to victims of acts of racial discrimination and facilitate access to recourse procedures by vulnerable groups"').

93 U.N. CERD Report, Concluding Observations of the Comm. on the Elimination of Racial Discrimination-Botswana, \14, U.N. Doc. CERD/C/BWA/CO/16 (2006).

94 Id. ๆ 14.

95 U.N. CERD Report, Consideration, Concluding Observations of the Comm. on the Elimination of Racial Discrimination-Madagascar, I 19, U.N. Doc. CERD/C/65/CO/4 (2004).

96 Id. $\$ 19$. 
ceedings has on indigent persons belonging to racial, ethnic and national minorities." In light of these disparities, and echoing the ABA's Resolution on civil counsel, the Committee recommended that the United States "allocate sufficient resources to ensure legal representation of indigent persons belonging to racial, ethnic and national minorities in civil proceedings, with particular regard to those proceedings where basic human needs-such as housing, health care, or child custody-are at stake." 98

Though the CERD Committee also reviews adversarial complaints brought by individuals against States Parties, I have found none in which the Committee reached a Civil Gideon issue on the merits; instead, most claims are dismissed because of failure to exhaust domestic remedies, often because of the party's failure to utilize existing legal aid assistance. Nevertheless, both CERD itself and the CERD Committee clearly recognize that implementation of the equality mandated under the treaty requires access to legal aid in civil as well as criminal matters. The increasing focus of the CERD Committee on this issue, as evidenced by its recent Concluding Observations on civil counsel directed to the United States, as well as its General Comment No. 31, supports the idea that the right to counsel in some civil matters is beginning to emerge as a recognized human right.

97 U.N. CERD Report, Concluding Observations of the Comm. on the Elimination of Racial Discrimination-United States of America, ๆ 22 CERD/C/USA/CO/6 (2008).

98 Id. 


\section{Other United Nations Documents}

The International Covenant on Economic, Social and Cultural Rights ("ICESCR") is the second half of the so-called International Bill of Rights, but it has not been ratified by the United States. ${ }^{99}$ The Covenant itself is silent on the right to counsel in civil matters, but in General Comment No. 7 on "the right to adequate housing," the Committee on Economic, Social and Cultural Rights considered the important substantive rights implicated by forced evictions. The Committee concluded that legal aid should be made available to affected individuals if at all possible:

Appropriate procedural protection and due process are essential aspects of all human rights but are especially pertinent in relation to a matter such as forced evictions which directly invokes a large number of the rights recognized in both the International Covenants on Human Rights. The Committee considers that the procedural protections which should be applied in relation to forced evictions include ... provision, where possible, of legal aid to persons who are in need of it to seek redress from the courts. ${ }^{100}$

The status of the Civil Gideon right as a general principle of law in the international community is further supported by reference to the Basic Principles on the Role of Lawyers, adopted in 1990 by the Eighth United Nations Congress on the Prevention of Crime and

99 Ryszard Cholewinski, The Human and Labor Rights of Migrants: Visions of Equality, 22 GEO. IMMIGR. L.J. 177, 183 (2008); Uta Oberdörster, Why Ratify? Lessons from Treaty Ratification Campaigns, 61 VAND. L. REV. 681, 708 (2008).

100 U.N. Human Rights Comm.-General Comment No. 7: The Right to Adequate Housing (Art.11.1): Forced Evictions: 20/05/97, I 15, 16th Sess., U.N. Doc. E/1998/22, Annex. IV (1997). 
the Treatment of Offenders. The United Nations Office on Drug and Crime Congresses are major global events held every five years, "bring[ing] together . . . government delegations, representatives of intergovernmental and nongovernmental organizations, specialized agencies, other United Nations entities, as well as individual experts" in one worldwide forum. ${ }^{101}$

Though they were adopted at a conference on criminal matters, the Basic Principles are broadly worded to encompass lawyers' roles in civil matters. Further, they note the importance of protecting economic, social, and cultural rights as well as civil and political rights, such as liberty. The first four paragraphs of the Basic Principles provide as follows:

1. Whereas adequate protection of the human rights and fundamental freedoms to which all persons are entitled, be they economic, social and cultural, or civil and political, requires that all persons have effective access to legal services provided by an independent legal profession....

2. Governments shall ensure that efficient procedures and responsive mechanisms for effective and equal access to lawyers are provided for all persons within their territory and subject to their jurisdiction, without distinction of any kind, such as discrimination based on race, colour, ethnic origin, sex, language, religion, political or other opinion, national or social origin, property, birth, economic or other status.

3. Governments shall ensure the provision of sufficient funding and other resources for legal services to the

101 United Nations Office on Drugs and Crime-The Eleventh Crime Congress, http://www.unodc.org/unodc/en/commissions/crime-congresses.html (last visited Aug. 30, 2008). 
poor and, as necessary, to other disadvantaged persons. Professional associations of lawyers shall cooperate in the organization and provision of services, facilities and other resources.

4. Governments and professional associations of lawyers shall promote programmes to inform the public about their rights and duties under the law and the important role of lawyers in protecting their fundamental freedoms. Special attention should be given to assisting the poor and other disadvantaged persons so as to enable them to assert their rights and where necessary call upon the assistance of lawyers. ${ }^{102}$

These Basic Principles are not part of a treaty and are not enforceable standards. No monitoring body exists that reviews compliance with these principles. However, the Basic Principles set out a baseline of accepted standards for provision of legal services, including the clear expectation that "[g]overnments shall ensure the provision of sufficient funding . . . for legal services to the poor . . . and other disadvantaged" individuals. ${ }^{103}$ As an international document, reflecting the broad consensus of the participants in the Eighth Congress, the Basic Principles provide further support for the proposition that a right to counsel in civil matters is an accepted standard that has the imprimatur of the international community.

\section{THE INTER-AMERICAN SYSTEM}

\section{A. The OAS and the American Declaration of the}

102 Basic Principles on the Role of Lawyers, Eighth United Nations Congress on the Prevention of Crime and the Treatment of Offenders, Havana, Aug. 27-Sept. 7, 1990, U.N. Doc. A/CONF.144/28 Rev.1 at 118 (1990).

103 Id. 


\section{Rights and Duties of Man}

In addition to its participation in the United Nations and United Nations treaty regimes, the United States participates in the regional international legal system of the Americas. In 1948, a few months before the Universal Declaration of Rights was finalized, the nations of the Americas at the Ninth International Conference of the American States adopted the American Declaration of the Rights and Duties of Man. ${ }^{104}$ At the same conference, the nations also adopted the charter for the Organization of the American States ("OAS"), an international organization consisting of thirty-five independent nations, including the United States. The OAS was created to "achieve an order of peace and justice, to promote their solidarity, to strengthen their collaboration, and to defend their sovereignty, their territorial integrity, and their independence." 105 The OAS Charter, a treaty that is binding on all member states of the OAS, contains an explicit right to free civil counsel:

The Member States, convinced that man can only achieve the full realization of his aspirations within a just social order, along with economic development and true peace, agree to dedicate every effort to the application of the following principles and mechanisms .... Adequate provision for all persons

104 See American Declaration of the Rights and Duties of Man, AG/RES. 1591 (XXVIIIO/98), available at http://www.oas.org/juridico/English/ga-Res98/Eres1591.htm.

105 Charter of the Organization of American States, supra note 30, at art. 1, opened for signature Apr. 30, 1948, 2 U.S.T. 2394, 1609 U.N.T.S. 119 (entered into force Dec. 13, 1951) amended by Protocol of Buenos Aires, O.A.S.T.S. No. 1-A (1967), further amended by Protocol of Cartagena di India, O.A.S.T.S. No. 66 (1985), further amended by Protocol of Washington, OEA/Ser.A/2 Add. 3 (SEPF) (1992), further amended by Protocol of Managua, OEA/Ser.A/2 Add. 4 (SEPF) (1993). 
to have due legal aid in order to secure their rights. ${ }^{106}$

This provision has been construed to extend to both civil and criminal matters. ${ }^{107}$

Following on the Charter, the American Declaration also articulates rights such as the "Right to equality before the law" (Article II), and the "Right to fair trial" (Article XVIII). The latter article provides:

Every person may resort to the courts to ensure respect for his legal rights. There should likewise be available to him a simple, brief procedure whereby the courts will protect him from acts of authority that, to his prejudice, violate any fundamental constitutional rights. $^{108}$

While it is not formally a treaty, the Declaration is considered by OAS bodies to be a source of binding obligation for OAS member states. As a member of the OAS, the United States is held to the standards of the Declaration as well as the Charter.

106 Lidman, Civil Gideon as a Human Right, supra note 15, at 784; see also Charter of the Organization of American States, supra note 30, at art. 45.

107 Lidman, Civil Gideon as a Human Right, supra note 15, at $784 \mathrm{n.118}$ (citing EILEEN SkinNider, The Responsibility OF States to Provide Legal Aid (1999), http://www.icclr.law.ubc.ca/Publications/Reports/beijing.pdf).

108 Organization of American States, American Declaration of the Rights and Duties of Man art. XVIII, O.A.S. Res. XXX, adopted by Ninth International Conference of American States (1948), reprinted in Basic Documents Pertaining to Human Rights in the InterAmerican System, OEA/Ser.L.V/II.82 doc.6 rev.1 at 17 (1992). 


\section{B. Components of the Inter-American System}

\section{The Inter-American Commission on Human Rights}

In 1959, OAS created the Inter-American Commission on Human Rights ("the Commission") with its headquarters in Washington, D.C. The Commission is "a permanent body which meets in ordinary and special sessions several times a year."109 The Commission endeavors to protect human rights based on three documents: The OAS Charter, the Declaration, and the American Convention on $\mathrm{Hu}-$ man Rights ("the Convention"). The Commission "[r]eceives, analyzes and investigates individual petitions which allege human rights violations," issues recommendations, and refers cases to the InterAmerican Court of Human Rights. ${ }^{110}$

\section{The American Convention on Human Rights}

In 1969, certain nations in the Americas adopted the Convention, which was ratified and deposited in 1978. ${ }^{111}$ The Convention is a treaty. Its purpose is to "consolidate in this hemisphere, within the framework of democratic institutions, a system of personal liberty and social justice based on respect for the essential rights of man."112 Drafters of the Convention drew its provisions directly from the guid-

\footnotetext{
109 Inter-American Comm'n on Human Rights, What is the IACHR?, http://www.cidh.org/what.htm.

110 Id.

111 See Organization of American States, American Convention on Human Rights "Pact of San Jose, Costa Rica," Nov. 22, 1969, O.A.S.T.S. No. 36, 1144 U.N.T.S. 123, available at http://www.oas.org/juridico/english/sigs/b-32.html (last visited Aug. 27, 2008).

112 See id.
} 
ing principles from the Declaration. However, the United States is a signatory but has not ratified the Convention, and is thus not subject to its standards. ${ }^{113}$

\section{Inter-American Court of Human Rights}

The American Convention created the Inter-American Court of Human Rights to adjudicate cases and to issue advisory opinions concerning State members. The Court sits in Costa Rica. In contrast to the earlier-created Commission, the Inter-American Court is an adjudicatory body that hears and rules on specific cases of human rights violations. ${ }^{114}$ The Court and Commission operate together to oversee compliance with the American Convention, with the Commission exercising somewhat broader jurisdiction as a body created by the OAS. ${ }^{115}$ For example, the Commission directly reviewed United States' practices, and the practices of other nonsignatories to the American Convention, in light of the American Declaration. ${ }^{116}$

\section{Jurisprudence of the Inter-American System}

In 2007, the Inter-American Commission on Human Rights

\footnotetext{
113 Id.

114 Inter-American Court of Human Rights, Court Statute, http://www.corteidh.or.cr/historia.cfm.

115 INTER-AM. COURT OF HUMAN RightS ANNUAL REPORT 2007 , http://www.corteidh.or.cr/docs/informes/Inf\%20anua\%202007\%20ING.pdf

116 Ramos v. United States, Case 12.430, Inter-Am. C.H.R., Report No. 1/05, OEA/Ser.L/V/II.124 doc. 5 qा 43-44 (2005) (noting that the application of the death penalty must comply with the standards of the American Declaration). See also Edwards v. Bahamas, Case 12.067, Hall v. Bahamas, Case 12.068, Schroeter v. Bahamas, Case 12.086, InterAm. C.H.R., Report No. 48/01, OEA/Ser.L/V/II.111 doc. 20 rev. If 4 (2000) (holding Bahamas to standards of the American Declaration though it is not a signatory to the Convention); Canada, Decision of the Commission as to the Admissibility, Case 11.092, Inter-Am. C.H.R., Report No. 27/93, 19. 29-30 (1993) (holding Canada to the standards of the American Declaration).
} 
issued a report entitled, Access to Justice as a Guarantee of Economic, Social and Cultural Rights: A Review of the Standards Adopted by the Inter-American System of Human Rights. ${ }^{117}$ This report synthesized the general human rights criteria for access to justice, and included a specific discussion of the right to counsel applicable to both criminal and civil cases. As summarized in the report's introduction, "[b]oth the Inter-American Court and the IACHR have made it an obligation in certain circumstances to provide free legal services to persons without means in order to prevent infringement of their right to a fair trial and effective judicial protection." 18 The factors pertinent in determining when counsel must be provided are (1) the resources of the individual involved; (2) the difficulty of the issues raised; and (3) the significance of the rights at issue. ${ }^{119}$ However, according to the Commission, certain constitutional proceedings always require the provision of counsel. ${ }^{120}$

As the Commission's comprehensive report describes, the Inter-American Court has explicitly recognized that the fundamental right to a free trial, protected by the American Declaration and the American Convention, can be violated by denial of access to counsel in certain civil matters. In 2003, the Inter-American Court of Human Rights reviewed a petition filed by Mexico seeking an advisory opin-

117 InTER-AM. COMm'N ON Human Rights, ACCESS to Justice as a Guaranty of ECONOMIC, SOCIAL, AND CULTURAL RIGHTS A REVIEW OF THE STANDARDS ADOPTED BY THE INTER-AMERICAN SYSTEM OF HUMAN RIGHTS 47 (2007) \ 182, OEA/Ser.L./V/II.129 doc. 4. The Commission also noted the importance of access to counsel in its recent report entitled "Access to Justice for Women Victims of Violence in the Americans."

118 Id. $\$ 6$.

119 Id. 16.

120 Id. ๆ 7. 
ion on the general denial of rights to migrant workers. The rights at issue consisted of labor rights such as payment of overtime and seniority rights, but the petition also raised questions concerning the interrelationship between labor rights and the denial of due process and equality rights. ${ }^{121}$ The information presented to the Court included data concerning United States legislation barring federally-funded legal services lawyers from providing representation to certain migrant workers. In particular, a brief filed by fifty civil rights, labor, and immigration organizations in the U.S. explained that "[t]he 1974 Legal Services Corporation Act created the Legal Services Corporation, and its programs are prohibited from providing legal aid for, or in representation of, most migrants who are not legal permanent residents." 122

In considering the general claim under international law, including the American Declaration on the Rights and Duties of Man, the American Convention on Human Rights, the Universal Declaration and the ICCPR, the Court concluded:

The right to judicial protection and judicial guarantees is violated for several reasons . . . [including] by the negative to provide him with a free public legal aid service, which prevents him from asserting the rights in question. In this respect, the State must guarantee that access to justice is genuine and not merely formal. ${ }^{123}$

121 Mexico Case, 2003 Inter-Am. Ct. H.R. (ser. A) No. 18, at 1 (Sept. 17, 2003) (advisory opinion)

122 Id. at 52.

123 Id. at 102, 126. See Sarah H. Cleveland, Legal Status and Rights of Undocumented Workers, Advisory Opinion OC-18/03, 99 AM. J. INT'L. L. 460, 460 (2005). 
In short, like the HRC construing the ICCPR and the CERD Committee enforcing the equality provisions of CERD, the Inter-American Court recognized in this advisory statement that the fundamental guarantees of basic labor protections under the Inter-American system were undermined by the denial of civil legal assistance to undocumented workers.

This result was foreshadowed in 1990, when the InterAmerican Court considered the implications of lack of domestic legal counsel for the Inter-American Commission's jurisdiction over individual petitions filed by nationals of member states. Two articles of the American Convention on Human Rights, 46(1)(a) and 46(2) set out the requirement that a petitioner exhaust domestic remedies prior to appealing to the Commission. The Commission requested that the Court issue an advisory opinion addressing whether the exhaustion requirement applies "to an indigent, who because of economic circumstances is unable to avail himself of the legal remedies within a country." 124 The Court concluded that "if it can be shown that an indigent needs legal counsel to effectively protect a right which the Convention guarantees and his indigency prevents him from obtaining such counsel, he does not have to exhaust the relevant domestic remedies."125 Thus, the Court effectively refused to reward those states that denied representation to the indigent by barring further proceedings against them before the Inter-American Commission.

124 Exceptions to the Exhaustion of Domestic Relations, 1990 Inter-Am. Ct. H.R. (ser. A) No. 11, I 2 (Aug. 10, 1990) (requested by the Inter-American Commission on Human Rights).

125 Id. $ๆ 31$. 


\section{Other OAS Documents}

In addition to the Charter, Declaration, and Convention, the OAS has issued other documents that indicate the importance this international body places on providing a right to counsel in certain civil matters. For example, in 2000, the OAS adopted the Inter-American Convention Against Corruption designed to, among other things, provide formal protections for whistleblowers. ${ }^{126}$ The OAS then developed a Model Law to protect freedom of expression against corruption, and urged member states to adopt this model as part of their coordinated efforts against corrupt practices. Recognizing the importance of counsel in protecting the rights of whistleblowers, Article 13 of the Model Law creates "a right to counsel for purposes of this statute, in recognition that efforts to challenge corruption and defend against retaliation require knowledgeable representation."127

\section{CONCLUSION}

This Article provides a snapshot of the international legal status of the right to counsel in civil cases, reviewing the international human rights treaties, commentary, and other documents most pertinent to the United States. The international law discussed here supports the conclusion that the Civil Gideon right is an emerging right in international jurisprudence. International bodies have been particularly apt to recognize this right when inequalities and threats to

\footnotetext{
126 Organization of American States, Inter-American Convention Against Corruption, Mar. 29, 1996, 35 I.L.M. 724.

127 Organization of American States Explanatory Notes, Inter-American Convention Against Corruption, Organization of American States Model Law, art. 13, available at www.whistleblower.org/content/press_detail.cfm?press_id.=53 (last visited Aug. 28, 2008).
} 
individuals' fundamental interests are exacerbated by the lack of legal assistance. Since the United States is a participant in several of these international treaty regimes, this international jurisprudence concerning Civil Gideon is highly relevant to evaluating whether human rights and the interests of justice are adequately served by the current United States system. 
Touro Law Review, Vol. 25, No. 1 [2013], Art. 15 